\title{
Role of renal denervation in the treatment of arterial hypertension: a review
}

Orekhov A. Yu., Karazhanova L. K.

\begin{abstract}
Regardless of the fact that arterial hypertension is the focus of modern cardiology, resistance to therapy is still an important public health problem with adverse medical, social, and economic consequences. Aim of study: systematizing the available results of studies of the effectiveness of renal denervation in the treatment of patients with resistant $\mathrm{AH}$. Search within databases (PubMed, Cochrane Library) was performed for randomized controlled studies of second-generation catheterassisted renal denervation and sham-controlled studies. We have used PRISMA protocol for preparing our paper. The neutral results of the SYMPLICITY HTN-3 study significantly weakened the interest of practical cardiology in this procedure, however recently published data from the EnligHTNed IDE, SPYRAL HTN OFF MED, and SPYRAL HTN-ON MED studies confirmed the effectiveness and safety of the technique. As the result the second-generation catheters (multielectrode catheters) used for renal denervation confirmed the effectiveness and safety of the procedure, and also expanded the technique usage beyond resistant hypertension. However, the question of the reliability of long-term effects of the procedure still remains, as well as establishing mechanisms to identify predictors of planned intervention responsiveness.
\end{abstract}

Keywords: renal denervation, device-based therapy, hypertension, sympathetic nervous system, resistant.

\section{Relationships and Activities: none.}

Non-profit Joint-stock Company "Semey Medical University", Semey, Republic of Kazakhstan.

Orekhov A. Yu. * ORCID: 0000-0001-7201-1399, Karazhanova L. K. ORCID: 00000001-6664-3293.

*Corresponding author: orekhov-andrei@list.ru

$\mathrm{AH}$ - arterial hypertension, $\mathrm{BP}$ - blood pressure, $\mathrm{Cl}$ - confidence interval, SBP systolic blood pressure.

Received: 29.04.2021

Revision Received: 07.06.2021

Accepted: 07.06.2021

(cc) BY 4.0

For citation: Orekhov A.Yu., Karazhanova L. K. Role of renal denervation in the treatment of arterial hypertension: a review. Russian Journal of Cardiology. 2021;26(9): 4497. (In Russ.) doi:10.15829/1560-4071-2021-4497

\section{Роль почечной денервации в лечении артериальной гипертонии}

Орехов А. Ю., Каражанова Л. К.

\begin{abstract}
Несмотря на то, что артериальной гипертензии (АГ) уделяется много внимания в современной кардиологии, резистентность к медикаментозной терапии по-прежнему остается важной проблемой общественного здравоохранения, сопряженной с неблагоприятными медицинскими, социальными и экономическими последствиями. Цель: систематизировать результаты исследований по эффективности денервации почечных артерий в лечении пациентов с резистентной АГ. В ходе работы осуществлялся поиск рандомизированных контролируемых испытаний (PubMed, Кокрановская библиотека) и плацебоконтролируемых исследований по ренальной денервации с помощью катетеров второго поколения. Мы использовали протокол PRISMA для подготовки статьи. Результаты исследования SYMPLICITY HTN-3, не показавшие преимуществ денервации почечных артерий, значительно ослабили интерес практической кардиологии к данной процедуре, однако недавно опубликованные данные исследований EnligHTNed IDE, SPYRAL HTN OFF MED и SPYRAL HTNON MED подтвердили эффективность и безопасность метода. В результате катетеры второго поколения, используемые для ренальной денервации, подтвердили эффективность и безопасность процедуры, а также показали возможность применения техники не только при резистентной АГ. Тем не менее, вопрос об эффективности процедуры в отдаленном периоде остается открытым. Кроме того, требуется дополнительное изучение и поиск предикторов ответа на лечение с помощью ренальной денервации
\end{abstract}

Arterial hypertension is one of the most pressing challenges of modern cardiovascular medicine, as well as the main modifiable cause of cardiovascular mortality worldwide. Currently, there is a large scientific base in understanding the pathophysiology and clinical significance of conditions associated with increased blood pressure (BP). Significant progress has also been
Ключевые слова: денервация почечных артерий, терапия на основе устройств, артериальная гипертензия, симпатическая нервная система, резистентность.

\section{Отношения и деятельность: нет.}

Некоммерческое акционерное общество "Медицинский университет Семей", Семей, Республика Казахстан.

Oрехов А. Ю. * - ассистент кафедры, докторант PhD, ORCID: 0000-0001-72011399, Каражанова Л. К. - д.м.н., профессор, ORCID: 0000-0001-6664-3293.

*Автор, ответственный за переписку (Corresponding author): orekhov-andrei@list.ru

Рукопись получена 29.04.2021

Рецензия получена 07.06.202

Принята к публикации 07.06.2021

Для цитирования: Орехов А. Ю., Каражанова Л. К. Роль почечной денервации в лечении артериальной гипертонии. Российский кардиологический журнал. 2021;26(9):4497. doi:10.15829/1560-4071-2021-4497

made in expanding the evidence showing that a decrease in $\mathrm{BP}$ is accompanied by a significant reduction in premature morbidity and mortality. A large number of available and highly effective methods of correcting arterial hypertension (AH) does exist, including nonpharmacological methods of treatment, an arsenal of drugs that reduce not only the level of $\mathrm{BP}$, but also have 
a wide range of pleiotropic effects. Nevertheless, the control of BP remains quite low in developed countries and even more so in developing countries [1].

A contributor to the lack of achieving the target BP is resistant $\mathrm{AH}$, which means the inability to achieve the target values of systolic BP or diastolic BP, despite the recommended treatment strategy, i.e., lifestyle modification and the use of optimal or maximum tolerated doses of three or more drugs, including a diuretic [1]. The prevalence of truly resistant $\mathrm{AH}$ is about $12-15 \%$ [2], while taking into account the study's results (SPRINT) [3] and the revised target values of BP in the recently published American and European recommendations, an increase in the number of patients with uncontrolled $\mathrm{AH}$ is expected.

Numerous causes of the phenomenon of resistance are considered in the literature. Normally, risk factors for developing hypertension resistant to drug therapy include age, female gender, higher baseline systolic BP, obesity, type 2 diabetes, metabolic syndrome, left ventricular hypertrophy, as well as increased salt and alcohol consumption and low level of education [2]. As the research results show, the high activity of the sympathetic nervous system is of great importance in the pathophysiology of resistance. Increased activity of the sympathetic nerves plays a crucial role in the development of $\mathrm{AH}$. It has been found that activation of efferent renal nerves can cause delayed sodium excretion, decreased renal blood flow, and activation of the renin-angiotensinaldosterone system. Moreover, afferent sympathetic nerve fibers have been shown to increase the sympathetic tone of the entire body [4].

The technique of sympathetic denervation of the renal arteries, proposed in 2003 by H. Levin and M. Gelfand, nowadays can serve as an additional, and sometimes alternative, method of treating hypertension [5]. The absolute safety of the procedure is no longer in doubt; however, the effectiveness of the method has been the subject of discussion more than once.

Thus, the aim of this work was to systematize the available results of studies on the effectiveness of sympathetic denervation of the renal arteries in the treatment of patients with resistant hypertension.

\section{A new chapter in sympathetic denervation of the renal arteries}

The results of the first and certainly significant studies of Symplicity HTN-1 [6] and Symplicity HTN-2 [7] were of great importance in determining the role of sympathetic denervation of the renal arteries in the treatment of resistant hypertension; the data obtained facilitated to the interest in studying the role of the sympathetic nervous system in the genesis of resistance, and also put catheter technologies as one of the most promising treatment methods. Open studies of Symplicity HTN-1 and Symplicity HTN-2 evaluated the effect of monoelectrode radiofrequency denervation of the renal arteries, showed a significant influence in reducing office $\mathrm{BP}$ in patients with resistant $\mathrm{AH}$, in addition, the procedure was absolutely safe, no significant adverse events were detected, including a decrease in kidney function. In view of this, the results of Symplicity HTN-3, a prospective, randomized, Charm - controlled study, were unexpected [8]. The results of this study did not show a significant advantage in reducing office BP in patients after renal denervation in comparison with a fictitious procedure. As a result, there was a significant decrease in interest, both in the scientific and practical environment, in this procedure. However, even in this study, the absolute safety of renal denervation was shown.

For a long time, the possible reasons for this result have been discussed in the literature. The analysis of confounding factors conducted by Kandzari DE is curious [9]. So, according to the analysis, three critical issues are important: during this series of studies, mono electrode radiofrequency catheters were used, procedures were performed mainly in the proximal parts of the renal arteries, the group included patients with severe resistant $\mathrm{AH}$ with severe vascular wall disorders, as well as low patient adherence in terms of pharmacotherapy. Thus, the authors propose to take into account the following factors in future planned studies and routine clinical practice (with changes):

1. Procedure: Distal intervention shows greater effect and possibly additional impact;

2. Population: respondents of renal denervation may be patients with pronounced BP variability;

3. Patients: Adherence to therapy is a key factor; the procedure should be considered not only in patients with resistant $\mathrm{AH}$.

In support of this, the results of histological studies have shown that in some cases, the renal arteries do not have true sympathetic plexuses at the level of the proximal segments, in addition, it is shown that it is in the distal segment that a closer contact with the artery wall is revealed [10]. According to this, a greater number of ablation points and their localization in the distal segments is associated with a higher efficiency of the procedure.

Further understanding of the features of sympathetic regulation of renal hemodynamics led to the creation of a second generation of catheters - multielectrode catheters. As a result of studies using these modifications of catheters, reliable evidence of the effectiveness and safety of renal denervation was obtained.

One of these studies was EnligHTN ${ }^{\mathrm{TM}}$ Renal Denervation System [11], the first prospective multicenter non-randomized trial involving 39 patients with resistant hypertension, which examined the effectiveness of generation 2 catheters. It is important to note that the study evaluated the long-term effect of the procedure - the duration of follow-up was 24 months. As a result, it was 
Key features of some studies (revised, Lucas Lauder, 2019) [19]

\begin{tabular}{|c|c|c|c|}
\hline FEATURE & SYMPLICITY HTN-3 & SPYRAL HTN-OFF MED & EnligHTNed IDE \\
\hline Centers & The USA & The USA, Europe, Japan, Australia & The USA \\
\hline Procedure technique & $\begin{array}{l}\text { Radiofrequency monoelectrode } \\
\text { catheter }\end{array}$ & $\begin{array}{l}\text { Radiofrequency monoelectrode } \\
\text { catheter, Medtronic Vascular, } \\
\text { Santa Rosa, CA, USA }\end{array}$ & $\begin{array}{l}\text { Radiofrequency monoelectrode } \\
\text { catheter, St. Jude Medical, St. Paul, } \\
\text { MN, USA }\end{array}$ \\
\hline Ablation site & Proximal segment & Proximal and distal segment & Proximal segment \\
\hline Inclusion criteria (by BP), mm Hg & $\begin{array}{l}\text { Office } S B P \geqslant 160 \mathrm{~mm} \mathrm{Hg}, \\
\text { SBP by } A B P M \text { data } \geqslant 135 \mathrm{~mm} \mathrm{Hg}\end{array}$ & $\begin{array}{l}\text { Office } S B P \geqslant 150-179 \mathrm{~mm} \mathrm{Hg}, \\
\text { SBP by } A B P M \text { data } \geqslant 140-169 \mathrm{~mm} \mathrm{Hg}\end{array}$ & Office SBP $\geqslant 160 \mathrm{~mm} \mathrm{Hg}$ \\
\hline Experimental group & Sham-control & Sham-control & None \\
\hline Antihypertensive therapy & Standard therapy & No medication intake & Standard therapy \\
\hline Primary endpoint & Office BP & ABPM & Office BP \\
\hline $\begin{array}{l}\text { Degree of BP reduction compared } \\
\text { to control }\end{array}$ & $\begin{array}{l}-2 / 39 \mathrm{~mm} \mathrm{Hg}(95 \% \mathrm{Cl}-6.89 \\
\text { to } 2 / 12, \mathrm{p}=0 / 26)\end{array}$ & $\begin{array}{l}-3,9 \mathrm{~mm} \mathrm{Hg}(95 \% \mathrm{Cl}-6,2 \\
\text { to }-1,6, p=0.0005)\end{array}$ & - \\
\hline
\end{tabular}

Note: ABPM - ambulatory blood pressure monitoring, BP — blood pressure, $\mathrm{Cl}$ - confidence interval, SBP - systolic blood pressure.

possible to achieve a decrease in office BP in comparison with the initial one by 19/7, 26/9, 25/7, 23/7, 27/9 after 1 , $3,6,12,24$ months, respectively $(\mathrm{p}<0.0001)$.

The SPIRAL Pivotal series of studies used a spiral multielectrode catheter for renal denervation. The results of SPYRAL HTN-OFF MED are interesting [12], a randomized, sham-controlled trial that included patients who either had not previously received therapy, or patients after 4 weeks of discontinuation of antihypertensive drugs, to confirm the effectiveness of renal denervation in reducing blood pressure. The study included 2 groups of patients randomized in a 1:1 ratio - the renal denervation group $(n=166)$ and the sham procedure group $(n=165)$. As a result, a significant reduction in blood pressure was achieved; thus, the difference in treatment between the two groups for 24-hour systolic blood pressure (SBP) was $-3.9 \mathrm{~mm} \mathrm{Hg}$ (95\% confidence interval (CI) from -6.2 to -1.6 ), for office SBP the difference was $-6.5 \mathrm{~mm} \mathrm{Hg}$ (from -9.6 to -3.5 ). At the same time, again, the safety of the procedure was shown, no serious complications associated with the device or procedure were identified.

Thus, this study raises a legitimate question - whether renal denervation is an alternative to antihypertensive therapy. The peculiarity of SPYRAL HTN-OFF MED is precisely in the absence of pharmacological treatment, respectively, we consider not only the population of patients with truly resistant $\mathrm{AH}$. Pseudo-resistance to treatment, namely, the lack of an adequate level of adherence to treatment, may become a new indication for this procedure. The literature discusses possible future scenarios for the use of renal denervation as a procedure that not only reduces the number of drugs taken [13], but also as an alternative to pharmacological therapy in general.

Another study, SPYRAL HTN-ON MED [14], evaluated the effectiveness of renal denervation with spiral catheters against the background of ongoing antihypertensive therapy. According to the preliminary analysis of 80 patients, there was a significant decrease in the average SBP and diastolic BP in the renal denervation group: the average daily SBP $-7.0 \mathrm{~mm} \mathrm{Hg}(95 \% \mathrm{CI}-12.0-$ $2.1 ; \mathrm{p}=0.0059)$, the average diastolic $\mathrm{BP}-4.3 \mathrm{~mm} \mathrm{Hg}$ (95\% CI -7.8-0.8; $\mathrm{p}=0.0174)$.

Thus, the use of second-generation catheters shows a reliable effect according to sham studies; the proven absolute safety of the renal denervation procedure is important (Table 1).

\section{Sympathetic denervation of the renal arteries: expanding the horizons}

Nowadays, it is almost obvious that renal denervation is an effective and safe method of controlling blood pressure, however the literature is actively discussing 4 main issues of widespread use of the procedure, namely: 1) How does it work?; 2) Who to treat?; 3) How to treat?; 4) How long does effect last? [15].

It is crucial to determine the name of the "Perfect" patient for sympathetic denervation of the renal arteries; the search for predictors of the response to therapy remains open. According to one of the largest guidelines on renal denervation [5], most likely the procedure cannot have a class-effect, a positive result can be achieved in a certain number of patients. So, today, difficult-tocontrol (and not always resistant) AH is still a priority, especially given the rather low level of adherence to therapy, which, according to one of the meta-analyses, is $59 \%$ [16]. In addition, renal denervation may be recommended in high- and very high-risk patients with any severity of $\mathrm{AH}$, especially in the presence of hypertensionmediated organ damage or severe concomitant diseases (Table 2).

Unfortunately, the data available today do not allow us to verify with high accuracy the respondent patients for the procedure of renal denervation. The available potential predictors have a rather low level of reproducibility of the results in real practice [5]. However, the 
Table 2

\section{Current and potential candidate hypertensive populations for renal denervation therapy (out of 5, revised)}

\begin{tabular}{|c|c|c|}
\hline Patient group & Pro & Con \\
\hline \multicolumn{3}{|l|}{ Current candidates } \\
\hline $\begin{array}{l}\text { Difficult-to-control hypertensive patients (with office SBP between } 140 \\
\text { and } 170 \mathrm{~mm} \mathrm{Hg} \text { or diastolic BP between } 90 \text { and } 109 \mathrm{~mm} \mathrm{Hg} \text { ) }\end{array}$ & $\begin{array}{l}\text { Current target population Solid evidence } \\
\text { base }\end{array}$ & Narrow group \\
\hline \multicolumn{3}{|l|}{ Potential candidates } \\
\hline CAD patients, especially patients undergoing $\mathrm{PCl}$ & $\begin{array}{l}\text { Very high-risk patients } \\
\text { Low rates of BP control in daily care }\end{array}$ & $\begin{array}{l}\text { Prolonged procedure } \\
(\mathrm{PCl}+\text { renal denervation })\end{array}$ \\
\hline CHF with HTN & $\begin{array}{l}\text { Pathogenetically justified } \\
\text { Large number of patients } \\
\text { Pilot studies exist }\end{array}$ & Not well-recognized as candidates \\
\hline
\end{tabular}

Note: AF — atrial fibrillation, BP - blood pressure, CAD - coronary artery disease, CHF - chronical heart failure, HTN — hypertension, PCI - percutaneous coronary intervention, SBP - systolic blood pressure.

heart rate (HR), which reflects the degree of hypersympathicotonia, is the most reasonable marker of the clinical effectiveness of renal denervation [17]. Thus, in the previously mentioned study of SPYRAL HTN-OFF MED [12], a heart rate exceeding the median (73.5 beats per minute) showed a significant predictive role in reducing the average daily Systolic BP, daily diastolic BP, and office sBP [18].

\section{Conclusion}

Despite the attitude towards renal denervation after the publication of the results of the SYMPLICITY HTN-3 study, the procedure is currently experiencing a kind of renaissance. Positive data obtained in a series of studies (EnligHTNed IDE, SPYRAL HTN OFF MED, SPYRAL HTN-ON MED) using a new generation of catheters - multispiral catheters - proved the

\section{References}

1. Williams B, Mancia G, Spiering W, et al. 2018 ESC/ESH Guidelines for the management of arterial hypertension. Eur Heart J. 2018;39:3021-104. doi:10.1093/eurheartj/ ehy339.

2. Carey RM, Calhoun DA, Bakris GL, et al. Resistant hypertension: Detection, evaluation, and management a scientific statement from the American Heart Association. Hypertension. 2018;72:53-90. doi:10.1161/HYP.0000000000000084.

3. SPRINT Research Group, Wright JT Jr, Williamson JD, Whelton PK, et al. A Randomized Trial of Intensive versus Standard Blood-Pressure Control. N Engl J Med. 2015;373(22):2103-16. doi:10.1056/NEJMoa1511939. Erratum in: N Engl J Med. 2017;377(25):2506

4. Johns EJ, Kopp UC, DiBona GF. Neural control of renal function. Compr Physiol 2011;1(2):731-67. doi:10.1152/physrev.1997.77.1.75

5. Mahfoud F, Azizi M, Ewen S, et al. Proceedings from the $3^{\text {rd }}$ European Clinical Consensus Conference for clinical trials in device-based hypertension therapies. Eur Heart $\mathrm{J}$. 2020;41(16):1588-99. doi:10.1093/eurheartj/ehaa121.

6. Krum H, Schlaich M, Whitbourn R, et al. Catheter-based renal sympathetic denervation for resistant hypertension: a multicentre safety and proof-of-principle cohort study. Lancet. 2009;373(9671):1275-81. doi:10.1016/S0140-6736(09)60566-3. effectiveness and confirmed the safety of the procedure. However, skepticism remains in the clinical sphere, in particular due to the presence of unresolved issues, including limited data on the long-term effectiveness of the procedure, the assessment of the impact of renal denervation on organ damage mediated by hypertension, and most importantly, the identification of patients with the highest probability of responding to the procedure of renal denervation based on a reliable and reproducible selection method. In this paper, the authors tried to summarize the available data on the effectiveness and safety of the procedure, as well as to show possible prospects for using the procedure of sympathetic denervation of the renal arteries outside the framework of resistant arterial hypertension.

Relationships and Activities: none.

7. Esler MD, Krum H, Sobotka PA, et al. Renal sympathetic denervation in patients with treatment-resistant hypertension (The Symplicity HTN-2 Trial): A randomised controlled trial. Lancet. 2010;376(9756):1903-9. doi:10.1016/S0140-6736(10) 62039-9.

8. Bhatt DL, Kandzari DE, O'Neill WW, et al. A Controlled Trial of Renal Denervation for Resistant Hypertension. N Engl J Med. 2014;370(15):1393-401. doi:10.1056/ NEJMoa1402670.

9. Kandzari DE, Mahfoud F, Bhatt DL, et al. Confounding factors in renal denervation trials: Revisiting old and identifying new challenges in trial design of device therapies for hypertension. Hypertension. 2020;76(5):1410-7. doi:10.1161/HYPERTENSIONAHA. 120.15745 .

10. Garcia-Touchard A, Maranillo E, Mompeo B, et al. Microdissection of the human renal nervous system: Implications for performing renal denervation procedures. Hypertension. 2020;76(4):1240-6. doi:10.1161/HYPERTENSIONAHA.120.15106.

11. Worthley SG, Wilkins GT, Webster MW, et al. Safety and performance of the second generation EnligHTNTM Renal Denervation System in patients with drug-resistant uncontrolled hypertension. N Engl J Med. 2017;373(22):2103-16. doi:10.1016/j. atherosclerosis.2017.04.022. 
12. Böhm M, Kario K, Kandzari DE, et al. Efficacy of catheter-based renal denervation in the absence of antihypertensive medications (SPYRAL HTN-OFF MED Pivotal): a multicentre, randomised, sham-controlled trial. Lancet. 2020;395(10234):1444-51. doi:10.1016 S0140-6736(20)30554-7.

13. Weber MA, Mahfoud F, Schmieder RE, et al. Renal Denervation for Treating Hypertension: Current Scientific and Clinical Evidence. JACC Cardiovasc Interv. 2019;12(12):1095-105. doi:10.1016/.j.jin.2019.02.050

14. Kandzari DE, Böhm M, Mahfoud F, et al. Effect of renal denervation on blood pressure in the presence of antihypertensive drugs: 6-month efficacy and safety results from the SPYRAL HTN-ON MED proof-of-conceptrandomised trial. Lancet. 2018;391(10137):234655. doi:10.1016/S0140-6736(18)30951-6.

15. Lurz P, Fengler K. Renal Sympathetic Denervation: Sparks of Hope With Some Uncertainties. JACC Cardiovasc Interv. 2019;12(12):1106-8. doi:10.1016/j.jcin. 2019.03.028.
16. Chowdhury R, Khan H, Heydon E, et al. Adherence to cardiovascular therapy: A metaanalysis of prevalence and clinical consequences. Eur Heart J. 2013;34(38):2940-8. doi:10.1093/eurheartj/eht295.

17. Kjeldsen SE, Esler MD. Take a blood pressure pill or undergo renal denervation? Lancet. 2018;391(10137):2298-300. doi:10.1016/S0140-6736(18)31126-7.

18. Böhm M, Mahfoud F, Townsend RR, et al. Ambulatory heart rate reduction after catheter-based renal denervation in hypertensive patients not receiving antihypertensive medications: Data from SPYRAL HTN-OFF MED, a randomized, shamcontrolled, proof-of-concept trial. Eur Heart J. 2019;40(9):743-51. doi:10.1093/ eurheartj/ehy871.

19. Lauder L, Wolf MA, Scholz SS, et al. Renal Denervation: Is It Ready for Prime Time? Curr Cardiol Rep. 2019:21(8):1-8. doi:10.1007/s11886-019-1164-2. 